Meta

Journal des traducteurs

Translators' Journal

\title{
Migrating Literature: Reading Geling Yan's The Banquet Bug and its Chinese Translations
}

\section{Yan Ying}

Volume 58, numéro 2, août 2013

URI : https://id.erudit.org/iderudit/1024176ar

DOI : https://doi.org/10.7202/1024176ar

Aller au sommaire du numéro

\section{Éditeur(s)}

Les Presses de l’Université de Montréal

ISSN

0026-0452 (imprimé)

1492-1421 (numérique)

Découvrir la revue

Citer cet article

Ying, Y. (2013). Migrating Literature: Reading Geling Yan's The Banquet Bug and its Chinese Translations. Meta, 58(2), 303-323. https://doi.org/10.7202/1024176ar

META

Résumé de l'article

Se penchant sur le roman de Geling Yan intitulé The Banquet Bug [La punaise des banquets] et sur ses traductions en chinois, le présent article fait état d'une exploration de ce que nous appelons " littérature migrante ", située dans un cadre transnational et traductionnel. La traduction est reconceptualisée à trois niveaux : contextuel, paratextuel et textuel. Tout d'abord, l'article examinera et contextualisera l'essence traductionnelle même de l'écriture migrante. Ensuite, il examinera deux éléments paratextuels, le titre et la couverture, afin de comprendre comment les paratextes recadrent l'écriture migrante et leur imposent parfois un sens inédit. Enfin, il discutera des pertes et des ajouts sémantiques en mettant l'accent sur les conséquences idéologiques et culturelles de ces processus. Par ailleurs, il soulignera la possibilité d'incorporer, dans le cadre de la littérature migratoire, des interprétations tirées de traductions issues d'autres langues, cultures ou formes médiatiques. 


\title{
Migrating Literature: Reading Geling Yan's The Banquet Bug and its Chinese Translations
}

\author{
YAN Y ING \\ Bangor University, Bangor, United Kingdom \\ y.ying@bangor.ac.uk
}

\begin{abstract}
RÉSUMÉ
Se penchant sur le roman de Geling Yan intitulé The Banquet Bug [La punaise des banquets] et sur ses traductions en chinois, le présent article fait état d'une exploration de ce que nous appelons «littérature migrante», située dans un cadre transnational et traductionnel. La traduction est reconceptualisée à trois niveaux: contextuel, paratextuel et textuel. Tout d'abord, l'article examinera et contextualisera l'essence traductionnelle même de l'écriture migrante. Ensuite, il examinera deux éléments paratextuels, le titre et la couverture, afin de comprendre comment les paratextes recadrent l'écriture migrante et leur imposent parfois un sens inédit. Enfin, il discutera des pertes et des ajouts sémantiques en mettant l'accent sur les conséquences idéologiques et culturelles de ces processus. Par ailleurs, il soulignera la possibilité d'incorporer, dans le cadre de la littérature migratoire, des interprétations tirées de traductions issues d'autres langues, cultures ou formes médiatiques.
\end{abstract}

\begin{abstract}
Using Geling Yan's The Banquet Bug and its Chinese translations as a case study, this article attempts to explore what I term "migrating literature" in a transnational and translational framework. Translation is reconceptualised at three levels: contextual, paratextual and textual. This article will first of all examine the very translational nature of immigrant writing from a contextualized reading. It will then look at how paratextual matters re-frame immigrant writing and sometimes impose meaning by analyzing two key paratextual elements, title and front cover. At the end, the gain and loss of meanings will be discussed at the textual level, with an emphasis on the ideological and cultural implications. It also points out the possibility of incorporating readings from translations in other languages and cultures, or translations in other media forms, into the framework of migrating literature.
\end{abstract}

\section{MOTS-CLÉS/KEYWORDS}

écriture migrante, Geling Yan, transnationalisme, recadrage immigrant writing, Geling Yan, transnationalism, re-framing

\section{Introduction}

Geling Yan was already an established writer before she left China for America in 1989. She continued to write prolifically in Chinese and is one of the most famous writers in the Chinese-speaking world. However, she was little known to the Western world until The Lost Daughter of Happiness (Yan 2001), ${ }^{1}$ translated from Fusang (Yan 1996), ${ }^{2}$ was published by Hyperion. This story about a Chinese prostitute in the $1860 \mathrm{~s}$ San Francisco Chinatown has received considerable accolade, especially among literary critics in the field of Asian American studies. Before that, a collection of her novellas was translated by her husband (L. Walker) and published as White Snake and Other Stories (Yan 1999), ${ }^{3}$ but it has largely been neglected. 
Probably encouraged by the success of The Lost Daughter of Happiness, Hyperion published another work of Yan's, her first and only English novel, The Banquet Bug, in 2006 (Yan 2006a) ${ }^{4}$. The story is a poignant revelation and satire of the corruption of contemporary Chinese society, of the contrast between the haves and have-nots, between the powerful and the powerless. Due to Yan's long-established popularity among the Chinese readers, it was soon translated into Chinese by Guo Qiangsheng, titled Fuyan Zhe [The banquet goer] and published by Sanmin Book in Taiwan in 2008 (Yan 2008a) ${ }^{5}$. The following year, it was introduced in the country the story originates from when Shaanxi Normal University Press published Guo Qiangsheng's translation in simplified Chinese in China.

This brief introduction to the two novels that have won Yan international acclaim, mainly through the medium of the English language, shows the transnational trajectory of her writings. Yan is not unique among immigrant writers. Milan Kundera and Vladimir Nabokov are examples at hand. Among Yan's fellow Chinese, the writing experience of Eileen Chang (Zhang Ailing) is also comparable to that of Yan's.

However, probably because of the disciplinary compartmentalization between ethnic literature and diaspora literature, not enough work has yet been done to explore the transnational trajectory of immigrant writings, especially in the field of Asian immigrant literature. This article therefore is an endeavor to establish a transnational framework to read writings such as Yan's. I propose the concept of “migrating literature" to emphasize the continuity in the transnational crossings, translations and transformations. The meanings are continuously generated during the process of transnational writing and translation, production and dissemination.

Using Yan's The Banquet Bug as a case study, and sometimes in conjunction with The Lost Daughter of Happiness, this article sets to map the trajectory of migrating literature in a transnational and translational framework. It attempts to reconceptualise translation at three levels: contextual, paratextual and textual. From a contextualized reading of The Banquet Bug, this article examines the very translational nature of immigrant writing. Then it looks at the second level of translation: how paratextual matters re-frame immigrant writing and sometimes impose meaning, as exemplified in titles and front covers, two of the key paratextual elements. Finally, the traditional sense of translation on the textual level will be examined to discover the meanings gained and lost in the linguistic transfer, especially the ideological and cultural implications for such a process. In order to suggest the inconclusiveness of the trajectory of migrating literature, I use coda instead of conclusion. In the coda, I suggest the limitation of the concept of migrating literature and its framework discussed in this study. Yet, it also points to the potential of this concept in engaging with other languages and cultures.

\section{Migrating Literature: Envisioning a Transnational and Translational Framework}

Literary works by immigrant writers tend to be separated in two directions either towards the adopted country or towards the native land, in other words, either as ethnic literature or as diaspora literature. They belong to the ethnic literature if written in the language of the adopted country, even if stories are exclusively about the writer's country of origin. If writers continue to write in the native tongue, their 
works are likely to be studied as the diaspora literature of their native land, notwithstanding that the work is about the country of their residence. For instance, literary works by Chinese immigrant writers written in English are usually studied in the field of Chinese American literature, while those written in Chinese are usually referred to as overseas Chinese literature. A defining factor of an author's literary identity, the writing language is the key issue in the disjuncture between ethnic literature and diaspora literature, or ethnic studies and diaspora discourse at large. This unresolved disjuncture also witnesses the decades-long dispute over whether to "claim America," an Asian Americans' political agenda raised by Maxine Hong Kingston, or to take a diasporic perspective, typically seen in Tu Wei-ming's advocacy of "cultural China" (Tu 1994: 13-14).

The mobility and flexibility as exemplified in Yan's choice of writing languages and positioning urges another framework that goes beyond the ethnic or diasporic dichotomy and seeks to bridge the disjuncture of the two. The transnational turn in postcolonial studies offers part of the answer. According to Kandice Chuh and Karen Shimakawa (2001: 5), the theory of transnationalism, grounded in recognition of global movements of capital and related migration of peoples, "describes and interrogates the possibilities of inhabiting and coopting cross-border mobility for the sake of envisioning communities bounded not principally by national identifications and investments." Thus a transnational perspective allows a vision that is not limited by national boundaries or literary departmentalization, and recognizes both "sites and transits" (Lim, Gamber et al. 2006) as suggested in the title of the first study of Asian American literature in the transnational framework.

In a special issue of Contemporary Literature dedicated to "immigrant fictions," Rebecca L. Walkowitz (2006: 528) points out in her introduction article that "literary studies will have to examine the global writing of books, in addition to their classification, design, publication, translation, anthologizing, and reception across multiple geographies." The transnational framework Walkowitz proposes not only includes the writing, but also expands to its packaging, marketing, reception and other forms of dissemination in and beyond one nation. Literary works are no longer produced within one country, one culture or one literary system. Like Yan's works, they can be conceived in one place and born in another, and continue to travel and disseminate in many other locations. Walkowitz refers to books of such nature as "transnational books" (2006: 529), and their writers as “migrant writers" (2006: 532). The nomenclature, together with the mention "immigrant fictions" in the volume title or other terms such as "diaspora writing" and "émigré writer" are, in many ways, similar and overlapping, all indicating the border-crossing experience. Yet these terms do not reflect the continuity in the transnational experience of the writer as well as the writing.

To represent "the location of literature" as in "multiple geographies" (Walkowitz 2006: 528), I propose the concept of "migrating literature" to refer particularly to the type of literature produced by migrant writers, which undergoes continuous transnational crossings, translations and transformations. The notion does not clash with existing terms, but rather provides a more inclusive and dynamic framework. It does not simply indicate the author's "migrating" experience - changes in his or her country of residence or passport identity. More importantly, it refers to the "migrating" experience of the writing. The emphasis on the continuity prompts more attention 
to the process of how new meanings have been generated through each re-location. Acquiring multi-layered meanings over different re-contextualizations and different translations, the writing, as it were, has developed its own life and can even morph into other forms that sometimes are independent of the author and source text.

To understand such a process of "literature migration," I suggest re-conceptualizing "translation" at three levels. The first level consists of highlighting the translational nature of the writing by immigrant writers. The second level takes the writing and its translations beyond the paired relationship between the writer and the translator, the original and the translation, and examines how the writing is re-positioned or, to use the term of narrative theory, "re-framed" in different contexts. The third level is based on the conventional sense of the term, which refers to the transformation between and across languages and cultures. Although these three levels are presented as emerging from the core of the original text towards the contextual and paratextual matters, they do not share a hierarchical relationship. Interpretations and meanings are constructed exactly through the interaction between these three levels.

\section{Translational Nature of Migrating Literature: To Write is to Translate}

For immigrant writers, especially those moving from East to West, from the third world to the first world, which involves disparate histories, ideologies and cultures, writing is essentially a process of translating, even more so when they write in a language that is not their mother tongue. This writing-as-translation thesis has been noted and discussed by critics. Red Chan (2007: 399), in her discussion of British Chinese literature, notes that "in both form and content, diasporic literature is coded with elements that are foreign to readers in the host culture." Thus, "[d]iasporic literature makes the boundary between creative writing and translation fuzzy: a diasporic fiction is simultaneously a text of translation" (Chan 2007: 399). This idea echoes Milan Kundera's ultimate claim that "translation is everything" (cited in Woods 2006: 17, italics original).

\subsection{The Choice of Language}

Taking writing as translating does not undermine the importance of the language itself. On the contrary, to understand migrating literature as translation, first of all, is to understand the significant role of the choice of language. For an immigrant writer, to make a conscious decision to write in a second language, and sometimes even a newly acquired language, is to enter another territory that marks differences in perspectives, sensibilities, themes, subject matter, and last but not least, style.

Steven Kellman (2000: ix), in The Translingual Imagination, proposes the notion of "literary translingualism" to summarize "the phenomenon of authors who write in more than one language or at least in a language other than their primary one." In the collection of essays and interviews on the topic following his monograph, Switching Languages: Translingual Writers Reflect on their Craft, Kellman (2003: ix) points out that "by expressing themselves in multiple verbal systems, [translingual writers] flaunt their freedom from the constraints of the culture into which they happen to be born." This sense of reaching freedom and shaking off shackles of the native culture through "translingualism" is often seen in the comments of Western 
media on the immigrant writers, especially those coming from a different ideological and political system. For example, on the back cover of Anchee Min's Red Azalea, the editor notes: "When Anchee Min left China in 1984 her knowledge of English was minimal. She tried to write this autobiography in her own tongue, but found it impossible. Only with the emotional freedom granted by a new language could she find her means of expression" (Min 2006) ${ }^{6}$. Similarly, Woods (2006: 117) concludes that "[f]or Kundera... writing in France and later writing in French seems to have been a form of release."

The correlation between one's "own tongue" and suppression, the "new language" and expression, is not necessarily a result of the inherent nature of the two languages. In fact, to write in a language that is not one's native tongue presents difficulties to overcome, even for Kundera. When he published his first novel in French, he had already been living in France for twenty years. Kundera still admitted, though in a "good sport" spirit, that when writing in French he had to "hurtle the obstacles of another language" (cited in Woods 2006: 117). As for Anchee Min, she did not reincarnate as an old Chinese self in English - despite her lack of linguistic proficiency - because the new language itself had an enabling power. Her decision was rather driven, as seen in the trend of autobiographical works in English by Chinese women in the 1990s, by the fact that the new culture, having offered the promise of "a free life," would lend a more willing ear to a story from a country of "the crazed" (to use the titles of two books by Ha Jin, another Chinese immigrant writer): a young girl's struggle for the leading role in the last "Yangbanxi" (Model Opera), "Red Azalea," commissioned by Madam Mao, Jiang Qing, before the end of the Cultural Revolution.

As for Yan, an established writer who had been writing in Chinese and for the Chinese for almost twenty years before she wrote her first novel in English, her different responses to the Chinese and Western media highlight the seeming paradox of both hurdles and freedom in expression that come with writing in another language, and more importantly, the importance of the audience. In the afterword of the Chinese version of The Banquet Bug (Fuyan zhe), Yan compares writing in Chinese and in English: while the former allows her to be "free without restraint," the latter makes her feel "anxious, uncomfortable," yet "stimulated as if getting an electric shock" (Yan 2009; my back translation). . She speaks of the experience of writing in English as a self-challenge and a discovery of self-potential. However, in an interview article by Reuters, entitled "Chinese writer finds freedom in English" - in the same vein as the editor's line in Red Azalea - Yan is quoted in the opening paragraph saying that "she likes writing in English: it gives her greater freedom" (Blanchard 4 April 2009). ${ }^{8}$ As with the case of Min, "freedom" is not attributable to the English language, but to the alleged "freedom of speech" found in the Englishspeaking Western countries, which clashes with the censorship in China.

Unlike some of her fellow immigrant writers, Yan did not take advantage of the "freedom" when she first arrived in America in 1989. After The Banquet Bug, she seems to have relinquished this "freedom" and has continued to write in Chinese she has published three more novels in Chinese after The Banquet Bug. To this day, it remains her only novel in English. Yan's explanations for the choice of language in fact depended on whom she was speaking to. In other words, the intended readership is a determining factor in choosing the language, as well as what is written/translated and how it is written/translated. 


\subsection{Reading the Writing in Context}

Since the publication of her first novel in 1985, Yan has been writing novels and short stories on a wide range of topics and settings, from the sent-down girl Xiuxiu in Tibet in the 1970s to Fusang, a Chinese prostitute in the San Francisco China Town in the late 1860s, from the Nanjing Massacre during the 1937 Japanese invasion in China to a love story between a Chinese student and an American diplomat. Almost twenty years into her writing career, Yan chose to write the story about the "banquet bug" in English. Personal reasons - whether it was to overcome the challenge of writing in another language or to speak the truth about China with granted freedom - need to be considered in conjunction with the social and historical background from which it emerged.

For a piece of work to be created, and subsequently marketed and sold well, it needs favorable circumstances of production, fitting into the fashions and ideologies of society. A brief look at the context of the literary scenes of Chinese immigrant writings and Western media's interest in China suggest that an English-speaking readership is ready for a story like The Banquet Bug. Along with the good reception of The Lost Daughter of Happiness, the popularity of other writings by Chinese immigrant writers also prepared Yan with a potential market. With the pinnacle success of Jung Chang's Wild Swans (1991), ${ }^{9}$ which has sold 10 million copies worldwide, the 1990s witnessed a burgeoning growth of autobiographies of Chinese women who have suffered and were traumatized mainly during the Cultural Revolution. At the turn of the $20^{\text {th }}$ century, winning the 1999 National Book Award for Waiting (1999) ${ }^{10}$ and several other prestigious literary prizes in America, Ha Jin marks yet another milestone for Chinese immigrant writing in English. In 2000, Gao Xingjian, a Chinese immigrant writer based in France, won the Nobel Prize of literature for his works in Chinese. Other writers such as Qiu Xiaolong, Yiyun Li, Xiaolu Guo and Hong Ying, either writing in English or through English translations, have reaped plaudits and prizes, and have made their way to the bestsellers.

Yan's The Banquet Bug deviates from the usual time setting of the Chinese immigrant writings - four decades from 1949, when the Communist Party came to power, to the Tiananmen Square Incident in 1989 ( $4^{\text {th }}$ of June). It brings to the Western reader a more updated picture of China, one that had hardly been featured in the works of her fellow immigrant writers from China, yet is more in tune with the news coverage of China in the Western media. Up till the year of 2005, during which Yan was writing the book, China had risen to be one of the leading economic powers in the world with its speed of growth ranking the fastest. Its spectacular development, uncompromised Communist-party political system and deepening social problems have kept the attention of the world. A random search of the news articles about China in December 2005 in The Guardian gives an example of Western opinion and interest. Between 13 December and 14 December 2005, The Guardian published three articles about China, the titles of which are respectively "Chinese communist party is collapsing,"11 "China among countries that jail most journalists"12 and "China to overtake Britain after Beijing underestimates growth." ${ }^{33}$ The Western media seemed to be held in awe, condemning, fearful yet amazed. Interestingly, topics of these three articles - corruption and disintegration of the Communist Party, severe media censorship and rapid economic growth - are all dealt with as major scenes in The 
Banquet Bug. This results in a banquet of "authentic" Chinese culinary curiosities brought one after another in a most elaborate form: literally in the sense that almost all of the courses mentioned in the book are quite inconceivable to the Western reader, and metaphorically in that Dan, the leading character, singularly bears witness to so many stories about social evils that might have happened in many different places over time, and they are all condensed into one book.

\section{Paratexts: Re-framing and Translation}

\subsection{Paratexts and Frames}

French narratologist Gérard Genette brings attention to the importance of paratext, the very frame of the text, and what lies outside it. In his seminal work, Paratexts: Thresholds of Interpretation, he writes that paratext is

[...] always the conveyor of a commentary that is authorial or more or less legitimated by the author, constitutes a zone between text and off-text, a zone not only of transition, but also of transaction: a privileged place of a pragmatics and a strategy, of an influence on the public, an influence that - whether well or poorly understood and achieved - is at the service of a better reception for the text and a more pertinent reading of it (more pertinent, of course, in the eyes of the author and his allies). (Genette 1997: 2, italics original)

The italicized "transaction" suggests an active dyad relationship, which on the one hand is "the author and his [sic] allies" who are mainly composed of the author and the publisher with its editor, cover page designer, invited reviewers and so on, and on the other, is the public reader. While I agree that the purpose of paratexts is to attract better reception and more influence, and ultimately, a higher sales figure in today's market economy, whether they necessarily provide in concert a "more pertinent" reading needs to be questioned. This part attempts to examine how paratextual matters translate and, consequently, transform the text through re-framing.

Genette's focus is more on the materials from authorial sources, such as author's preface, afterword, notes and interviews. However, paratexts as frames can also be understood in a more literal, and probably clichéd, sense: opening the book is like opening a door; what is displayed before the text begins and after it ends therefore acts like doorframes enclosing the text. Whether the frames are mahogany wood or silver metal or dark granite influences the reader's expectation and perception before and during the reading, serving as, in the words of Genette, "thresholds of interpretation." Paratexts, in this sense, mainly include book covers and sleeves, titles, blurbs, and prefatorial articles not composed by the author. I will focus on the title and the front cover, the two key elements in the book's very initial contact with the reader. Although the process of preparing these paratexts and the extent of author's participation in the process are never uniform or transparent, undoubtedly the publisher has an overall, if not sole, control over the front and back covers in between which the text is placed. They are the paratextual matters that belong to packaging and marketing, part of the distribution process the publisher prepares.

Marie Maclean (1991: 274), following Genette's scheme of dyad relationship, summarizes it also as a relationship "between the senders and receivers of the message." The messages sent by the author and the publisher are thus identified as one 
and the same. However, she also points out a more complex and dynamic relationship between the text and its paratexts: "The verbal frame, or paratext, may enhance the text, it may define it, it may contrast with it, it may distance it, or it may be so disguised as to seem to form part of it" (Maclean 1991: 274). The role of paratexts as frames in relation to the text seems more than complementing or boosting the latter so as to cast an influence on the reader; it also has a containing and controlling influence on the text. Such a view of the active role of frames is also shared by Mona Baker. In her politically charged study of "translation and conflict," Baker defines frames as "structures of anticipation, strategic moves that are consciously initiated in order to present a movement or a particular position within a certain perspective" (2006: 106, italics original). Therefore, that paratexts as frames indicate a triangular relationship between the author, the publisher and the reader is a more realistic and relevant picture.

The same triangular relationship can be applied to translation publications. Admittedly the translation involves more complicated relationships, such as between the author and the translator, between the original and the translation, between the publisher of the original and that of the translation. In order to illustrate the triangular relationship between the author, the publisher and the reader, and above all, examine the manipulating influence of paratexts, the translator's mediation is not considered in this part of discussion.

\subsection{Reading the Book Title as Paratext}

A book's title attempts to attract the reader's attention, offers guidance to the reader's approach to the text, and ultimately controls the reader's construction of the text. Genette (1997: 2) asks succinctly, "how would we read Joyce's Ulysses if it were not entitled Ulysses?" Like the power the namer assumes over the named, which is traceable to God in the Bible, to give a title is also an authoritative power. Maclean (1991: 27) considers the title "as a direct authorial speech act," and so does Genette (1997: 55-63) in his detailed analysis of various titles in the literary history. In fact, as will be demonstrated, the power to entitle a book does not belong to the author exclusively. On the contrary, it is sometimes beyond the control of the author, especially in translation.

This part will first of all look at the changes of the title in the English translation of Hong Ying's Ji'e de Nu'er and Yan's Fusang. It gives supportive evidence to the discussion that follows - changes of the title of the two English versions of The Banquet Bug and the Chinese translations. These transnational changes of the book titles reveal the cultural and ideological underpinnings of each act of titling: it reframes and redefines the story in a different way, with an aim to solicit specific associations and expectations in the intended readership.

The title of the English translation of Hong Ying's autobiography is changed from Ji'e de nu'er [Daughter of hunger] (Ying 1997/2000) ${ }^{14}$ to Daughter of the River (Ying 1998). ${ }^{15}$ It leaves out the thematic significance of "hunger" in the original title and plays down both its literal and symbolic weight. It transforms a personal feeling and subsumes it under a grander reference to the (Yangtze) River, one of the origins of the Chinese civilization and a symbol of the nation. The English translation of Yan's Fusang came out in 2001, three years after Daughter of the River, and is titled The Lost 
Daughter of Happiness. The similarities in the semantic and syntactic structure between the two titles are noticeable. It would not be an unfounded guess that the latter was influenced by the former. It is also likely that the title cashed in on the popular meta-narrative about daughter and mother in the ethnic and immigrant Chinese writings, such as Maxine Hong Kingston's The Woman Warrior (1976), ${ }^{16}$ Amy Tan's Joy Luck Club (1989) ${ }^{17}$ and, in particular, Jung Chang's Wild Swans, whose subtitle is Three Daughters of China.

In the eponym novel, Fusang is the name of the main character, one of the many anonymous Chinese prostitutes in the 1860s San Francisco. They have either been condemned and long forgotten or mentioned as an indiscriminate bunch in the history books. To give her a name is therefore to give her both individuality and identity; to give the book her name is therefore a dedication of the contemporary Chinese in America to their ancestor, loud and proud. What's more, the symbolic value of the name also lies in its relation to a type of hibiscus called fusang that grows in the area where Fusang is from. Originally from China, fusang has become highly recognized as the national flower of Malaysia and Panama, and the state flower of Hawaii. The dissemination of the flower reminds the reader of the Chinese diaspora and its ethnic pride. Wen Jin (2006: 576) offers another possible interpretation for the title Fusang: it "echoes the title of Stan Steiner's 1979 history Fusang: The Chinese Who Built America," and thus bestows on the novel the function of a historical account in recuperating the past.

Understandably the references to disseminating and taking root or to an out-ofprint history book would be lost to the majority of English-speaking readers. Yet, to change Fusang into The Lost Daughter of Happiness misses out on the first implication, which is crucial to the understanding of the story. It reverts Fusang from a specific person with a name back into a blurred and discolored picture, from the re-discovered to "the lost." The meaning of "the lost daughter of happiness" is rather ambiguous and opaque, bearing no obvious connection with the story. In fact, it reframes the book in an Orientalist fantasy, which the book is purported to subvert, featuring a Chinese woman as mystic and sensual. And significantly, being lost, she needs a parental savior. Such a re-framing is also evidenced and strengthened by the change of the book cover of the three editions, which will be discussed in the next section.

The title of Yan's The Banquet Bug, first published as such by Hyperion in America, has also undergone considerable changes, even with its two English editions. When Faber \& Faber published it in the UK, it was changed to The Uninvited, with a translation in Chinese, "Busu zhi ke qin qin" [The uninvited guest kiss kiss]. Both Chinese versions adopted "Fuyan zhe." Differences between these three titles are noticeable, from the derogatory indication of a bug to the mysterious guest, and to the neutral generic reference. With each change in the title, the story was re-framed in a different light.

Yan's story was reportedly inspired by a news report on CCTV about people who sneak into banquets to get free meals (Hu 19 November 2009). ${ }^{18}$ To call them "banquet bugs" is Yan's translation and coinage. As the Chinese tend to give big banquets and show their hospitality, especially on occasions like weddings and funerals, sometimes there is no fixed guest list. The Chinese use the term chi baishi de [those who eat free meals] to refer to such people, similar to free loader. Although the connotation is not 
positive, it does not have the dehumanizing and unpleasant associations with the bug and its parasitic existence.

However, Yan's naming is a double sword. Hers is a book about bugs in different forms, especially those in disguise. On the surface, it refers to people like Dan who take advantage of free meals, while in fact, it points more poignantly to those who host extravagant banquets. These people ruthlessly exploit and cheat other people to build their own wealth. While Dan is sent to prison, the latter can continue to enjoy banquets. In such a sharp contrast, Yan alludes to a saying by Zhuangzi, an ancient Chinese philosopher: "A petty thief is put in jail. A great brigand becomes ruler of a State (translated by Lin Yutang)." Contemporary China still mirrors the feudal China of thousands of years ago. Yan draws a picture of corruption in China: this economic and political super-power is infested with parasitic bugs eating it away from the inside. To use The Banquet Bug as a title for the whole narrative makes the revelation more pertinent.

The acerbic tone and rhetoric power of The Banquet Bug is lost in the title The Uninvited, of the UK version. The new title diverts the attention from probing the meaning of banquet bug while attempting to grab the attention by provoking curiosity. Yet, it brings to the story unbecoming associations. The titles The Uninvited or Uninvited have long been given to genres of mystery, horror and science fiction in films, TV series and novels, for example, the 2003 South Korean psychological horror film and its 2009 American remake. Associations with these genres do not fit the realistic picture of the story.

What re-frames the story even further is the Chinese translation of the title The Uninvited, Busu zhi ke qin qin [The uninvited kiss kiss]. It features more conspicuously than the English title on the front cover in bright Chinese red. To give it a Chinese translation is to indicate an ethnic marker, a sense of exoticism as well as authenticity. While the translation of The uninvited as Busu zhi ke is the standard dictionary version, together with qin qin it is almost inscrutable. It is not correct in grammar or relevant to the story. As it is not Chinese etiquette to kiss in greeting, the kiss has a strong sensual implication. To kiss the uninvited seems to suggests an unexpected sexual encounter. Set against a naked oriental woman, this Orientalist re-framing cannot be mistaken.

Travelling from America to the UK, the title The Banquet Bug changed from one with a dehumanizing metaphor to one with an implication of mystery and sex. When the story arrived in China, a neutral term referring to anybody who goes to a banquet was adopted. The connotation of fuyan zhe is too broad to make any association. Yet, it returns the human dignity to the type of people dehumanized to the status of an insect, especially because the term uses the written Chinese of the learned. As will be discussed, it is no coincidence that this kind of change, which I call "face-lifting," is also found in the text of Chinese translations.

The title is an essential paratext to the framing of the text. As has been demonstrated both in the case of Fusang and The Banquet Bug, each change of the title indicates an ideological and cultural re-framing. It presents the text in a particular perspective and gives it a new meaning. With the American and British publishers, there seems to be an Orientalist tendency in the titling, and consequently, framing of an Oriental story. This tendency is more clearly witnessed in conjunction with the design and change of book covers. 


\subsection{Reading the Front Cover as Paratext}

The importance of the book cover is approached and discussed from different perspectives in Matthews and Moody's Judging a Book by its Cover: Fans, Publishers, Designers, and the Marketing (2007). For example, Angus Phillips (2007: 19) notes the critical role the publisher assigns to the book cover as "reflected in the growth of the approval process for new designs," apparently because the book cover has an impact on the overall sales of the book. Not only the book cover influences the common readers in their purchases and readings, it also shapes, as Elizabeth Webby suggests (2007: 63-70), the views of cultural gatekeepers such as the judges of literary prizes. In short, the book cover has an impact on the reader's response that cannot be underestimated.

The design of the book cover suggests how the publisher intends to project the book to the reader, and the kind of response it hopes for. Novels, as John Mullan points out, have provided an especially rich field for book cover design. One of the reasons is that "they also challenge and liberate the designer to suggest through the cover not merely what the contents of the book might be, but also what might be its special qualities, its singular imaginative space" (Mullan 18 October 2003). ${ }^{19}$ Through the analyses of the book covers of The Banquet Bug and its various English editions and Chinese translations, this section reveals the kind of "special qualities" and "imaginative space" that have been projected onto the story by each cover. Reading covers of English editions of The Banquet Bug along with those of Daughter of Happiness again proves the persisting Orientalist fantasy in its re-framing of a Chinese story. The ideological re-framing is also seen in the sharp contrast between the cover design of the Taiwan version and the mainland version of The Banquet Bug.

The Lost Daughter of Happiness made its first appearance in an old black-andwhite photo of a Chinatown scene (Yan 2001; Appendix, Figure 1; see Note 1).

In the background is a crowd of men either in bowler hat and jacket or in cheongsam, who seem to be keenly engaged in a dispute. In the middle is a Chinese woman walking past the crowd, or walking away from them. She keeps her head down, and one of her bound feet emerges from underneath her skirt while stepping forward. Timid and tense, she is in contrast with the man in bowler hat behind her with his arms akimbo. In a highlighted yellowish tone, this Chinese woman is enframed in a lacy pattern together with the book title above her head and some of the background scene.

Undoubtedly, this woman is supposed to represent Fusang, the character. Using a historical picture, the cover seems to share the message of history and truth the story intends to impart. However, does this woman in the picture really share the identity with Fusang, apart from the fact that both of them are Chinese women in the San Francisco Chinatown over a century ago? In fact, the picture, titled "A Slave Girl in Holiday Attire, Chinatown, San Francisco," was taken around 1901 by Arnold Genthe, a photographer known for his photos of the San Francisco Chinatown. ${ }^{20}$ Considering that Fusang lives in the 1860 s, it is anachronistic to picture her as someone some four decades later. What matters most is that these four decades witness the rise of anti-Chinese animosity culminating in the issue of the Chinese Exclusion Act (1882) and its renewal in 1892, partly because Chinese prostitutes were considered 
as a Chinese vice and proof of their immorality. To use the picture of this young Chinese (certainly without her permission) - whether she is a lower class slave girl as claimed or an upper class lady - for the character of a prostitute is also a way of shanghaiing. It fits into the widespread claim of the time that "not one virtuous Chinawoman has been brought to this country" (cited in Yung 1995: 32).

However, this retrospection into the history of an ethnic minority as well as the nation, even though not entirely appropriate, was withdrawn when the paperback edition came out (Yan 2002; Appendix, Figure 2). ${ }^{21}$

A homely looking Chinese woman in the first edition changes into a sensuous geisha-looking Asian woman with heavy make-up. Her voluminous black hair merges with black background, setting her white skin and cherry-red mouth in relief. Her naked shoulders give away what is hidden behind the fan. Such a complete revamping can only suggest a deliberate manoeuver based on the assumption that the contrived sensuality and eroticism of an Oriental female body would cater to the reader's expectation better than a historical picture of real-life Chinatown.

When Faber \& Faber first published The Lost Daughter of Happiness in the UK, it continued to use the same image as Hyperion's. However, in its most recent 2010 print, the front cover adopted a color-picture of a contemporary-looking Asian woman (Yan 2010a). ${ }^{22}$

In the new cover, cherry-red lips and pitch-black eyebrows were dropped; her face and lips look colorless, and her eyes sad. Yet, the fan, an oriental token, is still present. This front cover drops to some extent the strong sensuous tones of the previous one. Nevertheless, both covers show complete disregard for the historicity of the story, as if Chinese women of any era are simply flat faces with almond-shaped eyes and dark long hair, timeless in the Orientalist fantasy.

Through these covers, Yan's story about an early Chinese immigrant in America is re-framed in a way that can be summed up, as Faber \& Faber suggests, in four key words: "Obsession; Asian interest; Gangsters; Love" (see Note 12).

This Orientalist obsession with Asian female bodies can also be traced in the cover designs of The Banquet Bug. The front cover of Hyperion's hard back edition features part of a naked female body - from the lower part of breasts down to the belly button - on which set two whole prawns (Yan 2006a; Appendix, Figure 3; see Note 4).

Admittedly, the story reaches the climax at a nudity banquet. In addition, as will be discussed in the next part, Yan does cater to Western readers' taste in her heavy references to culinary curiosities when writing in English. However, nudity banquet, long practiced in Japan and temporarily seen in a few places in China before it was banned in $2005,{ }^{23}$ is composed of aesthetically sophisticated arrangements of sushi, typically prepared raw seafood, and other decorations on a female body. In this cover image, the nudity banquet is translated simplistically into an undecorated naked female body and two cooked and unshelled prawns. The consumption of female body is (mis) represented in an even more crude way, and a story about corruptions and social problems in contemporary China is re-framed and marketed in glaring eroticism.

The cover of Hyperion's 2007 reprint is a complete change, from an erotic display of a female body to an almost Zen image with a lotus flower, a white China bowl, some bamboo sticks and a wooden plate set against clouds (Yan 2007a; Appendix, Figure 4). ${ }^{24}$ 
Cleansed of sexual implications and almost spiritually uplifting, this cover shares with the previous one a deploying of oriental cultural symbols, yet its suitability is just as doubtful.

When Faber \& Faber published the book re-titled The Uninvited in 2006, it brought back onto its cover the theme of naked woman and prawns (Yan 2006b). ${ }^{25}$ Interestingly, the Asian woman on this cover lies on her stomach, showing one side of her face and her whole bare back with waist curves, thus less directly erotic than the Hyperion's first print. Yet it might still be too revealing for the British sensibility. In the next print, the naked Asian woman is positioned obliquely in the top half of the book, and the prawns are replaced with a blue-white china saucer with sweet chili sauce (Yan 2007b). ${ }^{26}$

However, sweet chili sauce is as irrelevant as the cooked prawns to the nudity banquet, because it does not go with sushi.

The Chinese translation of the title is another proof of cultural misrepresentation and misappropriation. In this print, the lack of care for cultural accuracy is more clearly seen in the presentation of the Chinese translation of the title - it is printed upside down. Such negligence is suggestive of the misinterpreting and mis-framing of an oriental story.

From the cover changes of The Lost Daughter of Happiness to those of The Banquet Bug (including The Uninvited), this practice shows the persistent presence of eroticized Asian women. It would not be amiss to say that such strongly racially gendered and sexualized design aiming to allure the passing browser for consumption is analogous to Fusang and her sisters being lined up for a possible client.

The same type of framing would certainly not be adopted when the story was translated back into Chinese-speaking readers; Asian women's body or chopsticks would not have the same appeal to the reader. However, the Taiwan version and the mainland version are contrastive in the design of their front covers (Yan 2008a [see Note 5] and Yan 2009 [see Note 7], respectively).

The key tone of the Taiwan version (Yan 2008a; see note 18) is pitch-black, with the Chinese and English titles in red and yellow reminding the color scheme of China's national flag. On the top of the cover is a scene too dimly-lit to tell. Does this suggest that the contemporary China is a society too dark to probe? Considering the ideological opposition and political hostility between the two, it is not a wild guess.

The cover of the mainland version (Yan 2009; see note 19) bears no similarity in the design. Using white for the background, it is warm and bright in vibrant colors of orange and red in different shades. The splatter and splash of colors probably refers to the abstract paintings by Ocean Chen, a celebrity artist in the novel. Is it a rising dragon? Is it a galloping horse? Or is it an escaping fox, as the silhouette white shape seems to show? ${ }^{27}$ It is all subject to your interpretation. Strange, unusual, and diversified as suggested on the waist-band, China is multifaceted, although the story tells episodes of cruelty and violation of human rights in an extremely unfair society. The toning down in the re-framing is also supported by the excision of some parts sensitive to the Chinese censorship, as discussed in the next part.

The Orientalist tendency in the re-titling of Fusang is visually displayed through the changes in the front covers of The Lost Daughter of Happiness and The Banquet Bug over their different prints. Although Chinese translations of The Banquet Bug do not suffer from this symptom, they also re-frame the story so it fits into their 
respective ideological positioning. Therefore, the publisher and the author diverge in the messages sent through the front cover - the very first contact point between the book and its reader, and it is well-acknowledged that first impressions matter. Arguably, the publisher should get the author's authorization for the cover design. However, the sheer power difference between a big corporate publisher and a single author who is still awaiting the recognition from the Western world tells who has the say in this matter.

\section{At the Location of Translation}

In the previous two parts, it has been identified that migrating literature is, in a sense, a translation literature. In the case of The Banquet Bug, the translation started from the second the author decided to write her novel in English. The book has been continuously translated through paratextual re-framing, for example, re-titling and change of the cover. This last part will deal with migrating literature from the perspective of translation in its traditional sense, on the textual level, and identify the role of ideology, politics and national sensibility of the readership as a driving force in mediating the translation. I will discuss the English version and two Chinese versions separately so as to point out how the story acquires as well as loses meanings at different locations of translation.

\subsection{The English Translation: Translating Chinese Culinary Curiosities}

In his anthropological study of food in Chinese culture, K.C. Chang (1977: 11; 13) notes that "few other cultures are as food oriented as the Chinese" and that "the Chinese are probably among the peoples of the world most preoccupied with eating." Not surprisingly, food has been taken as an ethnic sign for the Chinese. In literary works by ethnic and immigrant Chinese writers, food is a distinctive and recurrent motif: Timothy Mo's Sour Sweet (1982/1985), ${ }^{28}$ Mei Ng's Eating Chinese Food Naked (1998), ${ }^{29}$ and David Wong Louie's The Barbarians Are Coming $(2000)^{30}$ to name just a few. In Hong Ying's Ji'e de nu'er, as mentioned earlier, the motif of food resonates even more loudly, exactly because of the absence of food. Being an ethnic sign, Chinese food is closely associated with identity, particularly because of its transnational displacement. Kenneth Lo made the distinction between Chinese cooking in China and Chinese food abroad. He once remarked that Chinese food, like everything else "suffers a sea change when removed from its native shores" (cited in Roberts 2002: 9). The same observation can be applied to a Chinese story written in Chinese and that written in English. A key factor in the change of Chinese cuisine crossing the sea is that it is served to a different set of diners, and as pointed out earlier, the main difference the language choice makes in the writing is the intended readership.

The Banquet Bug gives an illuminating example of this analogy between the two. It provides a feast of "authentic" culinary curiosities literally as well as metaphorically. In this part, I will focus on the literal sense of "culinary curiosities," because how they are represented and translated highlights the importance of diners/readers and the translational nature of migrating literature.

The culinary curiosities at the banquets reflect the corruption and hypocrisy of the banquet hosts and probably their guests, for example, a whole peacock served at 
a banquet hosted by "a nonprofit organization that supports young bird-watchers" (Yan 2007b: 9; see note 26); shark-fin soup that cost three hundred yuan a serving for the banquet after a fund-raiser called "Help Those Who Struggle in Poverty" (Yan 2007b: 75; see note 26). The extreme extravagance also serves as a foil to the starvation and deprivation ordinary people suffered and still suffer from. However, the way Yan dwells on the peculiarities of Chinese food culture verges on what Frank Chin calls "food pornography" (cited in Wong 1993: 55), that is, the exploitation of the exotic aspects of one's ethnic foodways. Yan's translation of Chinese culinary curiosities will be approached from two aspects: the semantic translation and the image translation.

Among many exotic delicacies at various banquets, two courses would certainly strike the Western reader's eyes. One is a gelatin "made of bull penises and seahorses," which supposedly "enhances virility"; the other is "frog uteruses," "a female aphrodisiac" (Yan 2007b: 179; see note 26). "Food pornography" is here presented in its very literal sense. Eating reproductive organs of animals is not particular to the Chinese. For example, "mountain oyster" considered as gourmet food in the American West is in fact beef testicles. However, it is the translation using the anatomical terms that the reader would relate to their own organs and find uneasy.

Bull penises can be bull pizzles, as pizzle refers specifically to the penis of an animal, especially a bull. What Yan calls frog uteruses have a name when used as food, hasma. It is a quite widely used ingredient in Chinese dessert soup, made from the dried fallopian tubes (rather than uteruses) of a type of frog. The organ references are hardly inferable from the terms in Chinese, niu bian [bull whip] and xueha [snow toad]. By translating them into bull penises and frog uteruses, Yan magnifies the perceived difference and produces a shocking effect.

The shocking effect of Chinese culinary curiosities is further enhanced by the way the image is composed and translated from an angle identified with the Englishspeaking reader, and hence defamiliarized to the Chinese local. One scene is about three peasants holding a banquet in their style to entreat Dan to write a report for them: "One dish is made of pig's feet and the others of pig entrails and organs. The pig-brain stew wobbles under a layer or red chilli gravy" (Yan 2007b: 84; see note 26). The scene, on one hand, shows the resourcefulness of these peasants in managing a feast within their very meagre means; on the other, it is exclusively composed of pigs' parts, which lacks variety and imagination, and is not typical of Chinese foodways. The grotesque presentation and consumption of such a feast, pig-brains in particular, would be considered almost cannibalistic by mainstream Western readers.

The shocking effect is achieved by sharing the readers' perspective, as well as their sensibilities. In one of the scenes in which Dan shares his banquet experience with his wife, he tells her about a dish made of a thousand crab claw tips: "Imagine: all that meat was once the tiny fingertips of those poor little monsters" (Yan 2007b: 4; see note 26). Yan transfers the Western readers' pity for crabs onto Dan, speaking out their mind through Dan. However, for an ordinary Chinese like Dan, crabs are a kind of seafood. They do not arouse sentimentalities of calling them endearingly "poor little monsters."

In translating Chinese culinary curiosities in the form of "food pornography," Yan caters to the Western palate for the "orientalness," and attaches to them the reader's perspectives and sensibilities. Through the Western perception, Chinese culinary curiosities presented in The Banquet Bug take on a new meaning. 


\subsection{Chinese Translation in Taiwan: Translating across the Taiwan Strait}

Guo Qiangsheng delivers a rather faithful translation, in the sense that it has no major excisions or changes of sentences found later in the mainland version. However, a careful reading still finds appropriations borne out by the political difference and historical hostility between mainland China and Taiwan, as well as national sensibility.

The condescending tone, to a degree of contempt, this translation has for the mainlanders can be found in some details. For example, Guo's translation of a scene in a foot-massage parlour:

(1) As the passage extends into deeper gloom, the air becomes stale, reeking with the odors of drinking, night meals, and slumbering bodies.

(Yan 2007b: 38; see note 26)

角道愈走愈昏暗, 空氣也愈來愈差, 一股奇怪的霉味混合著酒精、殘美剩飯, 還有橫七竪八許多人的體臭,..

[Passage is getting darker, air is also getting worse, a strange mouldy odour mixes with alcohol, leftovers, and smelly body odour of many people lying this way and that way,...]

(Yan 2008b: 47, translated by Guo; back translation by the author; see note 6)

The concise participle clause in English is turned into a longer and more elaborated sentence with additional descriptions. Night meals turns into leftovers, and slumbering bodies becomes an unsightly scene of many people lying in the same place. Also added is an unpleasant smell of mouldy odour.

This type of intensification in translating the undignified existence of the people across the strait is also seen in Guo's translation of political censorship. For example:

(2) It is a very touchy subject, and a newspaper has been shut down temporarily by the government because it published an article on a similar topic.

(Yan 2007b: 93; see note 26)

這個題目很敏感, 曾經有一家報紙就是因爲登了關於這方面的一篇文章,

結果被政府查封了。

[This topic is very touchy, once because a newspaper published an article on this topic, it was sealed up.]

(Yan 2008a: 114-115, translated by Guo; back translation

by the author; see note 5)

To shut down a magazine temporarily is to rectify it for its "unscrupulous" style and approach. It is censorship, but in Guo's translation, "temporarily" is left out to make it a far worse scenario that fits into some anti-China propaganda about the severity of Chinese censorship.

Some prejudice against the mainlander Chinese is detectable in Guo's translation. Likewise, the bias towards local Taiwanese people is also found in the defensive appropriation in the translation. In the foot-massage parlor, Happy, a sharp and cynical girl who prompted Dan's journalist attempt, makes a comment about some parlor clients from Taiwan: 
(3) "Another bunch of horny Taiwanese, reclaiming their motherland by fucking her daughters."

(Yan 2007b: 39; see note 26)

“又是一幫色瞇瞇的臺胞。覺得操了這裡的小姐就等於光復了祖國。”

["Another group of horny Taiwan compatriots. Thinking fucking working girls here is equal to reclaiming their motherland."]

(Yan 2008a: 48, translated by Guo; back translation by the author; see note 5)

Taiwanese is translated into Taiwan compatriots, an official reference to people living in Taiwan by the Chinese government, part of its adamant "one-China" policy rhetoric. However, it would not be used in casual conversations like this. What's more, fucking her daughters turns into fucking working girls here, thus narrowing down the group of women abused. Considering the nature of parlor, their behavior is justified in the translation. While Guo's adding thinking in the translation spells out the wishfulness on the part of Taiwanese, it reduces the curtness in Happy's remark. Thus her criticism loses its sharp edge, and her obvious contempt towards Taiwanese is also toned down.

This appropriation, probably to avoid upsetting the reader, is further evidenced by the fact that the parlor owner's smile in complicity with Happy is left out untranslated (Yan 2008a: 48, translated by Guo). In its translation to Chinese for the Taiwan reader, this mainland story of The Banquet Bug is also projected with another layer of perspectives and sensibilities, this time of the local Taiwanese.

\subsection{Chinese Translation in Mainland: Translating Censorship and National Pride}

When a story written for the Western readership exposing the dark sides of contemporary China came back to the Chinese reader, excisions and changes are inevitable considering the censorship in China. The Mainland version nominally adopts Guo Qiangsheng's translation, but in some parts, it features an invasive make-over, and small differences are abundant. Therefore, the Taiwan version and the mainland version have been considered in this article as two different translations rather than one. The changes are all editorial work, most of which falls into two categories due to censorship and national pride.

The censorship mentioned in the story mirrors the self-censoring excisions of the publisher. Large chunks of excisions are about "touchy" subjects (Yan 2007b: 93; see note 26). One of the most telling episodes is about a country girl who seeks her luck in Beijing, but is cheated. She takes her revenge, only to end up in prison. What makes it all the more chilling is that she is forced to abort the child conceived in prison and is then executed, nevertheless. Poor country girls not only have their dreams thwarted, but also are abused again and again by the rich, the powerful and, ultimately, the unfair social system. However, the most tragic part of the girl's story has disappeared in the mainland version.

The kind of protectiveness Guo has towards his fellow citizens is also present in the mainland version. There are many cases of what I call "face-lifting" in the changes to protect the sensibilities of the reader. For example, two of the young girls standing at the entrance of a restaurant welcoming the coming guests are described as 
"homely," and Yan notes in brackets that "in fact, they are all hard to look at" (Yan 2007b: 162; see note 26). These two uncomplimentary comments are deleted in the translation. Similarly, the unflattering description of President Wu's appearance, "his thick-cheeked, full-jawed face" (Yan 2007b: 219; see note 26), is also missing, although such a description would suit his characterization as part of the new rich.

Another type of "face-lifting" is in the price rise of sexual service by young women, at the top range as well as at the bottom. The price of the former is changed from "eighty or a hundred yuan" (Yan 2007b: 30; see note 26) in the English version to "two hundred to three hundred" (Yan 2009: 30; see note 7; back-translated by the author) in the mainland version, almost three times more. And the price of the latter, street-walking girls, has also risen from "fifteen" (Yan 2007b: 225; see note 26) to "twenty" (Yan 2009: 229; back-translated by the author; see note 7). It could be the case that Yan, writing from afar, did not have the accessible information on this, or the editor of the translation updated the information nearer to the reality. Whatever the reason, the value of fellow country women, even in a lowly profession, is protected and cared for.

The excisions are due to censorship by the political system, while the changes aim to protect the national pride of the reader. The mainland Chinese version of The Banquet Bug reaffirms the point that migrating literature is about translation in multiple locations and that new meanings in the writing are continuously produced on this endless migrating journey.

\section{Coda}

Using Geling Yan's The Banquet Bug in conjunction with her The Lost Daughter of Happiness as a case study, this study establishes a framework of looking at immigrant writings as migrating literature. Reconceptualizing translation at three levels - contextual, paratexual and textual, it points to the importance of considering the location of each translation as places where meanings are reproduced.

However, the framework of migrating literature in this study also has its limitations. Because of my own linguistic and cultural background, the discussion has been confined to the literary productions by Chinese immigrant writers in English. Therefore, the tracing of their migrating trajectory is also stopped at the Chinesespeaking and English-speaking countries. However, there are writers writing in more than two languages, and translations produced in different languages. Also there are translations of the same language produced by different translators, in different times and at different locations. While this framework cannot cover all these complications, it has potential for other researchers from other linguistic and cultural backgrounds to form a bigger and clearer map of the trajectory of migrating literature.

For a simple example, the front cover of the Thai translation of The Banquet Bug borrowed the UK title and its Chinese translation, but without the sensuous female body (Yan 2008b ${ }^{31}$ ).

The front cover of the Czech translation is a Kafkaesque picture with a number of chopsticks forming a fence with the man trapped behind (Yan 2010b ${ }^{32}$ ).

Researchers who know the language and culture will be able understand and answer the perspective from which the Thai and Czech publishers frame this book.

We can expand this quest for the trajectory of migrating literature into other forms of media. Reportedly, Warner has brought the copyright of the book and 
intends to ask a mainland Chinese director to make it into a film (see note 7). Through the medium of film produced in the international collaboration, how will it be translated and transformed?

\section{ACKNOWLEDGEMENTS}

I thank Mrs Lisa Barelli her kind authorization to reproduce the covers of Geling Yan's books published by Hyperion.

\section{NOTES}

1. YAN, Geling (2001): The Lost Daughter of Happiness. New York: Hyperion East. (Translated by Cathy Silber) See the originally colored cover on BookDepository.com. Visited on 15 March 2013, $<$ http://www.bookdepository.com/Lost-Daughter-Happiness-Geling-Yan/9780786866540>.

2. YAN, Geling (1996): Fusang. Xianggang; Tian di tu shu you xian gong si.

3. Yan, Geling (1999): White Snake and Other Stories. (Translated by Lawrence Walker) San Francisco: Aunte Lute Books.

4. YAN, Geling (2006a) The Banquet Bug. New York: Hyperion East. See the originally colored cover on BookDepository.com. Visited on 15 March 2013, <http://www.bookdepository.com/BanquetBug-Geling-Yan/9781401366650>.

5. YAN, Geling (2008a): Fuyan zhe. (Translated by Qiangsheng Guo) Taibei: Sanmin Book. Visited on 19 April 2012, <http://www.sanmin.com.tw/page-product.asp?pf_id=99u155T10v105F24C105 d67N111O127CERlJDs1861NcT>.

6. Min, Anchee (1996): Red Azalea. London: Indigo. Comment of the editor, back cover.

7. YAN, Geling (2009): Fuyan zhe. (Translated by Guo Qiangseng) Xi'an: Shaanxi Normal University Press. See cover at China.com.cn. Visited on 19 April 2012, <http://www.china.com.cn/book/ txt/2010-01/26/content_19305697.htm>.

8. Blanchard, Ben (4 April 2009): Chinese Writers Finds Freedom in English. Reuters. Visited on 10 September 2011, <http://www.reuters.com/article/idUSTRE53M00D20090423>.

9. Chang, Jung (1991): Wild Swans: Three Daughters of China. New York: Simon \& Schuster.

10. Jin, Ha (1999): Waiting. New York: Pantheon Books.

11. Miller, Simon (13 December 2005): Chinese communist party is collapsing. The Guardian. Visited on 10 September 2011, <http://www.guardian.co.uk/world/2005/dec/13/china.mainsection>.

12. Anonymous (Reuters) (14 December 2005): China among countries that jail most journalists. The Guardian. Visited on 9 September 2011, <http://www.guardian.co.uk/media/2005/dec/14/ chinathemedia.pressandpublishing $>$.

13. ElLiott, Larry (14 December 2005): China to overtake Britain after Beijing underestimates growth. The Guardian. Visited on 10 September 2011, <http://www.guardian.co.uk/business/2005/dec/14/ china.internationalnews $>$.

14. YING, Hong (1997/2000): Ji'e de nu'er. Chengdu: Sichuan wenyi chubanshe.

15. YING, Hong (1998): Daughter of the River. (Translated by Howard GoldblatT) New York: Grove Press.

16. Kingston, Maxine Hong (1976): The Woman Warrior; Memoirs of a Girlhood among Ghosts. New York: Knopf.

17. Tan, Amy (1989): The Joy Luck Club. New York: G. P. Putnam's Sons.

18. Hu, Xiao (19 November 2009): Yan Geling jiepou 'Yanhui Chong' lingan laizi Jiaodian Fangtan [Yan Geling explains the origin of the inspiration for "The Banquet Bug" as from Focus] People. com.cn. Visited on 9 September 2011, <http://book.people.com.cn/GB/69360/10407157.html>.

19. Mullan, John (18 October 2003): When it's acceptable to judge a book by its cover. The Guardian. Visited on 10 September 2011, <http://www.guardian.co.uk/books/2003/oct/18/art>.

20. Genthe, Arnold (1901 circa 5 years): A Slave Girl in Holiday Attire, Chinatown, San Francisco [photograph]. Picture History. Visited on 10 September 2011, <http://www.picturehistory.com/ product/id/19814>.

21. YAN, Geling (2002): The Lost Daughter of Happiness. $2^{\text {nd }}$ ed. New York: Hyperion. See the originally colored cover on BookDepository.com. Visited on 15 March 2013, <http://www.bookdepository. com/Lost-Daughter-Happiness-Geling-Yan/9780786887576 
22. YAn, Geling (2010a): The Lost Daughter of Happiness. Faber \& Faber. Visited on 10 September 2011, $<$ http://www.faber.co.uk/work/lost-daughter-of-happiness/9780571253562/>.

23. Anonymous (Agencies) (22 May 2005): China bans on meals served on naked women. China Daily. Visited on 10 September 2011, <http://www.chinadaily.com.cn/english/doc/2005-05/22/ content_444640.htm>.

24. Yan, Geling (2007a) The Banquet Bug. New York: Hyperion. See the originally colored cover on BookDepository.com. Visited on 15 March 2013, < http://www.bookdepository.com/Banquet-BugGeling-Yan/9781401374037>.

25. YAN, Geling (2006b): The Uninvited. London: Faber \& Faber. See the original colored cover here: Hilton, Isabel (9 December 2006): A banquet of corruption. The Guardian. Visited on19 April 2012, <http://www.guardian.co.uk/books/2006/dec/09/featuresreviews.guardianreview13>.

26. Yan, Geling (2007b): The Uninvited. London: Faber \& Faber. See the cover on the website of the publisher. Visited on 19 April 2012, <http://www.faber.co.uk/work/uninvited/9780571220533/>.

27. Thanks to the reviewer who pointed out this possibility.

28. Mo, Timothy (1982/1985): Sour Sweet. New York: Vintage Books.

29. NG, Mei (1998): Eating Chinese Food Naked. New York: Scribner.

30. Wong, David Louie (2000): The Barbarians are Coming. New York: G. P. Putnam's Sons.

31. YAN, Geling (2008b): The Uninvited. (Translated by นาลันทา คุปต์ [Nalanda Coptic]) Bangkok: Sangdad. Visited 15 March 2013, <http://www.sangdad.com/detailtext.aspx?cid=14\&bid=316>.

32. Yan, Geling (2010b): Příživník [Parasite]. (Translated by Pavla Horáková) Zlín: Kniha Zlín. Visited on 15 March 2103, <http://www.knihazlin.cz/track/prizivnik>.

\section{REFERENCES}

BAKer, Mona (2006): Translation and Conflict: A Narrative Account. London/New York: Routledge.

Chan, Red (2007): Chinese Flower in the English Garden: Hybridity and Cultural Translation in Liu Hong's The Magpie Bridge. Journal of Intercultural Studies. 28(4):397-412.

Chang, Kwang-chih, ed. (1977): Food in Chinese Culture: Anthropological and Historical Perspectives. New Haven/London: Yale University Press.

Chum, Kandice and Shimakawa, Karen, eds. (2001): Orientations: Mapping Studies in the Asian Diaspora. Durham: Duke University Press.

Genette, Gérard (1997): Paratexts: Thresholds of Interpretation. (Translated by Jane E. Lewin) Cambridge: Cambridge University Press.

Jin, Wen (2006): Transnational Criticism and Asian Immigrant Literature in the U.S.: Reading Yan Geling's Fusang and Its English Translation. Contemporary Literature. 47(4):570-600.

Kellman, Steven G. (2000): The Translingual Imagination. Lincoln: University of Nebraska Press.

Kellman, Steven G. (2003): Switching Languages: Translingual Writers Reflect on Their Craft. Lincoln: University of Nebraska Press.

Lim, Shirley Geok-lin, Gamber, John Blair, Sohn, Stephen Hong and Valentino, Gina, eds. (2006): Transnational Asian American Literature: Sites and Transits. Philadelphia: Temple University Press.

Maclean, Marie (1991): Pretexts and Paratexts: The Art of the Peripheral. New Literary History. 22(2):273-279.

Matthews, Nicole and Moody, Nickianne, eds. (2007): Judging a Book by its Cover: Fans, Publishers, Designers, and the Marketing. Hampshire: Ashgate Publishing.

Phillips, Angus (2007): How Books Are Positioned in the Market: Reading the Cover. In: Nicole Matthews and Nickianne Moody, eds. Judging a Book by its Cover: Fans, Publishers, Designers, and the Marketing. Hampshire: Ashgate Publishing, 19-30.

Roberts, J.A.G. (2002): China to Chinatown: Chinese Food in the West. London: Reaktion Books. Tu, Wei-ming, ed. (1994): The Living Tree: The Changing Meaning of Being Chinese Today. Stanford: Stanford University Press.

Walkowitz, Rebecca (2006): The Location of Literature: The Transnational Book and the Migrant Writer. Contemporary Literature. 47(4):527-545. 
Webby, Elizabeth (2007): Literary Prizes, Production Values and Cover Images. In: Nicole Matthews and Nickianne Moody, eds. Judging a Book by its Cover: Fans, Publishers, Designers, and the Marketing. Hampshire: Ashgate Publishing, 63-70.

Wong, Sau-ling Cynthia (1993): Reading Asian American Literature: From Necessity to Extravagance. Princeton: Princeton University Press.

Woods, Michelle (2006): Translating Milan Kundera. Clevedon: Multilingual Matters.

Yung, Judy (1995): Unbound Feet: A Social History of Chinese Women in San Francisco. Berkeley/ Los Angeles: University of California Press.

\section{APPENDIX}

Front covers of Geling Yan's books published by Hyperion

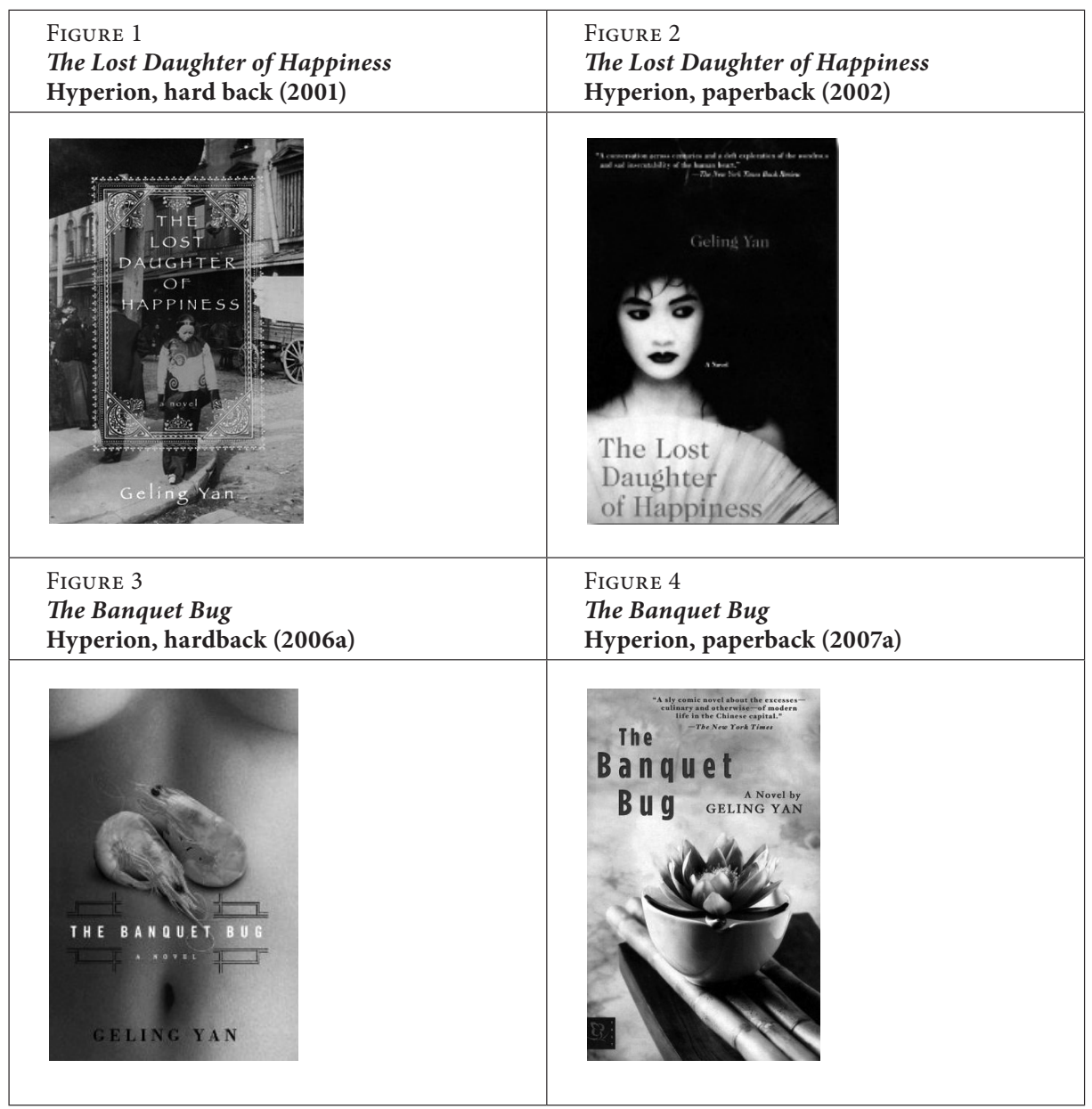

Reproduction authorized by Hyperion. 